\title{
Rational use of raw capers growing in Uzbekistan
}

\author{
Abdumumin Ganiev ${ }^{1 *}$, Bakhadirkhodja Temirov², Zamira Pazilbekova ${ }^{1}$, and \\ Mukhammetdin Tajetdinov ${ }^{1}$ \\ ${ }^{1}$ Tashkent State Agrarian University, 100140 Tashkent province, Uzbekistan \\ ${ }^{2}$ Ministry of Agriculture of the Republic of Uzbekistan, 100140 Tashkent province, Uzbekistan
}

\begin{abstract}
This article presents data on the export of raw materials and the results of pharmacological studies of caper buds for use in the pharmaceutical industry. For this, the volumes of export products for the last 2 years were studied and preclinical studies of the aqueous-alcoholic extract obtained from local plant materials were carried out in comparison with reference preparations. As a result, the aqueous-alcoholic extract obtained from local plant materials has reliable hypoglycemic activity comparable to the reference preparation "Gluqueir" capsule, but inferior to the synthetic preparation "Diabeton MR" $60 \mathrm{mg}$ tablets with modified release. The range of effective doses $\left(\mathrm{ED}_{30}, \mathrm{ED}_{50}\right.$ and $\left.\mathrm{ED}_{100}\right)$ was also established and the most effective dose was found.
\end{abstract}

\section{Introduction}

In recent years, a number of government decrees have been adopted in Uzbekistan on the rational use of natural resources of medicinal plants, the cultivation of rare and demanded species in the pharmaceutical industry, as well as their wider application in medical practice. In particular, the Decree of the President of the Republic of Uzbekistan dated April 10, 2020 No. PP-4670 "On measures for the protection, cultivation, processing of wild medicinal plants and the rational use of available resources" approved a list of provinces specializing in the cultivation of the main types of medicinal plants $[1,2]$. These plants also include prickly capers, which is recommended to be cultivated in the foothill and plain land areas of Bostanlyk and Akhangaran districts of Tashkent province, Zaamin, Bakhmal, Gallaaral and Farish districts of Jizzakh province, Pap and Chust districts of Namangan, Navoi, Kashkadarya and Surkhandarya provinces. It should be noted that prickly capers are drought-resistant (xerophytic) plants, for the cultivation of which soils with a light texture are suitable $[3,4]$.

Currently, raw materials from this plant are exported in large quantities abroad, but its production at local pharmaceutical companies has not yet been established. Spiny capers (Capparis spinosa L.) are a plant of the capers family (Capparacea), which has been widely used in folk medicine since ancient times [5]. It was used by Avicenna in various

* Corresponding author: akganiev@inbox.ru 
dosage forms for the treatment of wounds, diseases of the joints, head, respiratory tract and gastrointestinal tract $[6,7]$.

However, today the natural thickets of this plant are mainly harvested for export. In just 8 months of 2020, in the territory of the Jizzakh province, 12 exporters at the customs post of the Jizzakh Investment Fund exported 1,909 tons of capers in the amount of 3.2 million USD. Raw materials were mainly exported to Turkey and Spain by participants in the foreign economic activity of the Gallaaral, Zaamin and Sharof-Rashidov districts [8].

In January-August this year, the export of this product amounted to 2,300 tons (3.8 million USD), which is $4 \%$ or 94 tons (219,000 USD) more compared to the same period last year. During the same period in 2019, 2,200 tons (3.6 million USD) were exported, and during the year $-3,300$ tons (5.3 million USD) of raw materials. Products from capers were exported to Turkey ( $83 \%$ or 1,900 tons), Italy ( $11 \%$ or 238 tons), the USA ( $6 \%$ or 134 tons) and Spain (1\% or 19 tons). The main exporters were the enterprises of Jizzakh (79\% or 1.8 million tons), Namangan (10\% or 238 tons), Andijan (3\% or 81 tons), Samarkand (6\% or 134 tons) and Tashkent (2\% or 48 tons) provinces $[9,10]$.

Taking into account the high demand for raw capers in the food and pharmaceutical industries, the possibility of cultivating this plant from generative and vegetative organs is being studied. According to preliminary data, caper seeds are sown in autumn or early spring in layered or dry soils. High germination of seeds is achieved by stratification or scarification of seeds. For 1 hectare of area, $4 \mathrm{~kg}$ of seeds $(2,500 \mathrm{pcs})$ are used according to the $2 \times 2$ scheme and 5,000 seedlings according to the $1 \times 2$ scheme, thus, the seeds of the plant are $3-4 \mathrm{~cm}$. Considering the $30 \%$ loss of seedlings when planting the plant on the ground, it is recommended to plant 6,500 seedlings on 1 ha $[4,11]$.

It is well known that diabetes is a growing public health problem in both developed and developing countries. According to a report by the World Health Organization (August 2011), 346 million people have diabetes worldwide. It is also estimated that 3.4 million patients died in 2004 from complications associated with diabetes. Without urgent action, that number is likely to double by 2030. Experts estimate that two-thirds of people with diabetes die from heart disease and stroke. The risk of mortality from cardiovascular disease in people with diabetes is 2-4 times higher than in people without diabetes [5].

Medicinal plants have always been an important source for finding new preparations for human health problems. Traditionally, numerous herbs have been recommended for the treatment of diabetes. In addition, many researchers have reported the antidiabetic effects of many plants. However, in most cases these reports are supported by animal models and even in vitro studies, and there is limited evidence for their clinical utility. According to clinical studies, plants such as Aegle marmelos, Allium cepa, Gymnema sylvestre, Momordica charantia, Ocimum sanctum, Nigella sativa, Panax quinquefolius, Salacia reticulate, Silybum marianum and Trigonella foenum-graecum have shown hypoglycemic and hypoglycemic properties in some cases in diabetic patients $[6,12]$.

Along with the aforementioned antidiabetic agents, in recent years, researchers have also been interested in spiny capers (Capparis spinosa L.). It should be noted that capers grow everywhere in Uzbekistan, except for high-mountainous provinces and sandy steppes.

Many studies have demonstrated the antihyperglycemic and hypolipidemic activity of C. spinosa. The putative mechanisms involved in the antihyperglycemic effects of $C$. spinosa include decreased absorption of carbohydrates from the small intestine, inhibition of hepatic gluconeogenesis, increased tissue uptake of glucose, and protection of beta cell regeneration. This plant also improves cardiovascular disorders, liver damage, and nephropathy in animal models of diabetes, which refer to its antioxidant phytochemicals such as phenolic compounds, flavonoids, carotenoids, tocopherols, and terpenes. The antihyperglycemic and hypolipidemic activity of $C$. spinosa, along with its beneficial effect 
on diabetic complications, make it possible to recommend the plant for the treatment of diabetes [1-5].

In recent years, honey stevia (Stevia rebaudiana Bertoni) has been actively cultivated in Uzbekistan. In view of the sufficient industrial reserves of stevia leaves cultivated in Uzbekistan, a technology has been developed for obtaining tablets from this raw material by scientists of the Tashkent Pharmaceutical Institute [8].

Studies of stevia preparations show that, in addition to being useful as a sweetener, the aqueous and alcoholic extracts of this plant, its glycoside steviol, are also a pharmacological alternative to diabetes. In other words, these compounds have the necessary therapeutic potential for the natural treatment of endocrine diseases (such as obesity, diabetes, hypertension and dyslipidemia) that are relevant in the current context. These diseases are associated with metabolic syndrome, which is considered a public health problem due to its current prevalence. In addition to steviol glycosides, SR contains several phytochemicals, including phenols and flavonoids [9].

\section{Materials and methods}

Considering these circumstances, from the buds of prickly capers and leaves of honey stevia, harvested from local raw materials, an aqueous-alcoholic extract was obtained for further pharmacological studies. Indications for the use of the investigated aqueousalcoholic extract obtained from local plant materials are [4-7]:

- as an additional source of vitamins, microelements and other useful bioactive substances necessary to maintain the normal function of organs and systems;

- to maintain a specific diet and normal blood sugar levels (despite the sweet taste, the food supplement does not have glucose);

- recommended for maintaining normal lipid metabolism: prevents the accumulation of "bad" cholesterol in the blood and its deposition in blood vessels; it helps to maintain healthy vascular function;

- normalization of metabolism with low calorie content of products, which helps to avoid excessive accumulation of body fat and increase in body weight (obesity);

- strengthening the immune system and the body's resistance to various damaging factors (stress, colds, infections);

- for weakened persons, and in old age - as a general tonic, to improve appetite, to increase physical and mental activity;

- for a moderate decrease in blood pressure in the coronary vessels.

Recommended method of use: For adults and children over 12 years old, dilute 1 teaspoon $(5 \mathrm{ml})$ in 1 glass of warm boiled water 3 times a day before meals. It is not recommended to exceed the daily dose.

The preparation is contraindicated in case of individual intolerance to the components of the preparation, during pregnancy and lactation, as well as in children under 12 years of age.

The preparation is stored in its original packaging, in a dry, dark place at a temperature not exceeding $25^{\circ} \mathrm{C}$.

All preclinical studies were carried out on healthy white outbred rats (both sexes) weighing 150-180 g, and quarantined for at least 10-14 days [5].

The study of the hypoglycemic activity of the preparation was carried out on the model of adrenaline hyperglycemia [4]. It is known that parenteral administration of epinephrine causes hyperglycemia [6]. The experiments were carried out on 78 white outbred rats (both sexes) weighing 150-180 g, followed by division into groups of 6 animals each.

As reference preparations for the assessment of hypoglycemic activity, we used: 
- Comparison preparation No. 1 "Glouqueir" capsules, "Shrey Nutraceuticals \& Herbals Pvt. Ltd.", India;

- Comparison preparation No. 2 "Diabeton MR" 60 mg tablets with modified release, "Les Laboratoires Servier" France, manufactured by: "Les Laboratoires Servier Industrie" France.

Since the pharmacological action of the extracts is determined by the content of extractives (dry residue), then to conduct the study, and to accurately calculate the selected doses, we determined the dry residue of the alcohol extract (according to GF 11). The dry residue content in the alcoholic extract was $4.42 \%$.

Considering the fact that the composition of the investigated extract contains $70 \%$ ethanol, we carried out dealcoholization by evaporation under mild conditions (the extract was poured into an evaporation cup and dried under a hood at room temperature) to an almost dry residue (after such a procedure, ethanol almost completely absent in the extract), followed by bringing with purified water to the original volume, this procedure was carried out to eliminate the nonspecific activity of ethanol.

For this, the animals were deprived of food 24 hours before the experiment, while maintaining free access to water. 30 minutes before the introduction of adrenaline, the animals of the experimental groups were injected once with the preparations and the test extract:

1. Intact group (intact) - animals without manipulations;

2. Control group (control) - animals without treatment and prophylaxis;

3. Test group No. 1 - the animals were orally injected with an alcoholic extract in the form of a $4.42 \%$ dealcoholized solution, at a dose of $110.5 \mathrm{mg} / \mathrm{kg}$, in a volume of 0.5 $\mathrm{ml} / 200 \mathrm{~g}$;

4. Test group No. 2 - the animals were orally injected with an alcoholic extract, in the form of a $4.42 \%$ dealcoholized solution, at a dose of $221 \mathrm{mg} / \mathrm{kg}$, in a volume of $1 \mathrm{ml} / 200 \mathrm{~g}$;

5. Test group No. 3 - the animals were orally injected with an alcoholic extract in the form of a $4.42 \%$ dealcoholized solution, at a dose of $442 \mathrm{mg} / \mathrm{kg}$, in a volume of $2 \mathrm{ml} / 200 \mathrm{~g}$;

6. Test group No. 4 - the animals were orally injected with an alcoholic extract in the form of a $4.42 \%$ dealcoholized solution, at a dose of $663 \mathrm{mg} / \mathrm{kg}$, in a volume of $3 \mathrm{ml} / 200 \mathrm{~g}$;

7. Test group No. 5 - the animals were orally injected with an alcoholic extract in the form of a $4.42 \%$ dealcoholized solution, at a dose of $1105 \mathrm{mg} / \mathrm{kg}$, in a volume of $5 \mathrm{ml} / 200$ g;

8. Comparison group No. 1 - the animals were orally injected with the preparation "Gluqueir" capsules, "Shrey Nutraceuticals \& Herbals Pvt. Ltd.", India, in the form of a $10 \%$ suspension, at a dose of $500 \mathrm{mg} / \mathrm{kg}$, in a volume of $1 \mathrm{ml} / 200 \mathrm{~g}$;

9. Comparison group No. 2 - the animals were orally injected with the preparation "Gluqueir" capsules, "Shrey Nutraceuticals \& Herbals Pvt. Ltd.", India, in the form of a $10 \%$ suspension, at a dose of $1000 \mathrm{mg} / \mathrm{kg}$, in a volume of $2 \mathrm{ml} / 200 \mathrm{~g}$;

10. Comparison group No. 3 - the animals were orally administered the preparation "Gluqueir" capsules, "Shrey Nutraceuticals \& Herbals Pvt. Ltd.", India, in the form of a $10 \%$ suspension, at a dose of $1500 \mathrm{mg} / \mathrm{kg}$, in a volume of $3 \mathrm{ml} / 200 \mathrm{~g}$;

11.Comparison group No. 4 - the animals were orally injected with the preparation "Diabeton MR" $60 \mathrm{mg}$ tablets with modified release, "Les Laboratoires Servier" France, in the form of a $1.2 \%$ suspension, at a dose of $60 \mathrm{mg} / \mathrm{kg}$, in a volume of $1 \mathrm{ml} / 200 \mathrm{~g}$;

12. Comparison group No. 5 - the animals were orally injected with the preparation "Diabeton MR" 60 mg tablets with modified release, "Les Laboratoires Servier" France, in the form of a $1.2 \%$ suspension, at a dose of $120 \mathrm{mg} / \mathrm{kg}$, in a volume of $2 \mathrm{ml} / 200 \mathrm{~g}$;

13. comparison group No. 6 - the animals were orally injected with the preparation "Diabeton MR" $60 \mathrm{mg}$ tablets with modified release, "Les Laboratoires Servier" France, in the form of a $1.2 \%$ suspension, at a dose of $180 \mathrm{mg} / \mathrm{kg}$, in a volume of $3 \mathrm{ml} / 200 \mathrm{~g}$; 
Further, the animals of all groups, except for the intact one, were injected intraperitoneally with epinephrine hydrotartrate, in the form of a $0.036 \%$ solution, at a dose of $0.36 \mathrm{mg} / \mathrm{kg}$, in a volume of $0.1 \mathrm{ml} / 100 \mathrm{~g}$.

To assess the pharmacological activity, blood was taken from the heart province (in a state of ether anesthesia) 1 hour after the administration of adrenaline, and the pharmacological activity was judged by the normalization of blood glucose levels compared to the control. However, the main criterion for evaluating pharmacological (hypoglycemic) was the normalization of glucose levels.

To determine the glucose concentration, the blood was placed in a serological tube (red cap) without anticoagulant, and centrifuged at $3000 \mathrm{rpm}$ for 10 minutes. Next, the concentration of glucose in the obtained serum was determined on a biochemical analyzer "HUMALYZER Primus" (semi-automatic), manufactured by "Human GmbH" (Germany), with metrological characteristics: $340,405,500,546,620 \mathrm{~nm}$, reagent consumption $400 \mu \mathrm{l}$.

Also, based on the data obtained on the effective doses of the tested alcoholic extract, using a punch table, the $\mathrm{ED}_{30}, \mathrm{ED}_{50}$ and $\mathrm{ED}_{100}$ were calculated.

The results were processed by the method of variation statistics using the Student's test at $\mathrm{p}=0.05[9,10]$. The tables show the arithmetic mean values $(\mathrm{M})$, the corresponding standard errors of the mean $(\mathrm{m})$, Student's test $(\mathrm{t})$, the number of samples $(\mathrm{n})$, confidence limits (lower confidence limit $\div$ upper confidence limit).

\section{Results and discussion}

During the experiment, it was found (Table 1) that when modeling adrenaline hyperglycemia, there is a significant increase in glucose levels. However, with the introduction of the tested alcoholic extract in doses of $110.5 \mathrm{mg} / \mathrm{kg}, 221 \mathrm{mg} / \mathrm{kg}, 442 \mathrm{mg} / \mathrm{kg}$, $663 \mathrm{mg} / \mathrm{kg}$ and $1105 \mathrm{mg} / \mathrm{kg}$, a significant decrease in blood glucose levels occurs. It should be said that the highest hypoglycemic effect in the tested alcoholic extract was observed at a dose of $221 \mathrm{mg} / \mathrm{kg}$.

When considering changes from the "Glouqueir" capsule preparation, "Shrey Nutraceuticals \& Herbals Pvt. Ltd.", India, it was found that in doses of $500 \mathrm{mg} / \mathrm{kg}, 1000$ $\mathrm{mg} / \mathrm{kg}$ and $1500 \mathrm{mg} / \mathrm{kg}$, a significant decrease in blood glucose levels is observed. It should be said that the highest hypoglycemic effect in reference preparation No. 1 was observed at a dose of $1000 \mathrm{mg} / \mathrm{kg}$.

When considering the changes on the part of the preparation "Diabeton MR" $60 \mathrm{mg}$ tablets with modified release, "Les Laboratoires Servier", France, it was found that in doses of $60 \mathrm{mg} / \mathrm{kg}, 120 \mathrm{mg} / \mathrm{kg} 180 \mathrm{mg} / \mathrm{kg}$, a significant decrease in blood glucose levels was observed. It should be said that the highest hypoglycemic effect in comparison preparation No. 2 was observed at a dose of $120 \mathrm{mg} / \mathrm{kg}$.

If we compare the experimental data on the hypoglycemic activity of the most effective doses of the tested alcoholic extract and the comparison preparations, it turns out that the difference between the tested alcoholic extract and the preparation of "Glouqueir" capsules, "Shrey Nutraceuticals \& Herbals Pvt. Ltd.", India is not statistically reliable. However, when comparing the tested alcoholic extract with the preparation "Diabeton MR" $60 \mathrm{mg}$ tablets with modified release, "Les Laboratoires Servier", France, there is a statistically significant difference, while the hypoglycemic effect of the preparation "Diabeton MR" 60 mg tablets with modified release, "Les Laboratoires Servier France", significantly higher than that of the tested alcoholic extract (Table 1). 
Table 1. Results of studying the glucose content $(\mathrm{mmol} / \mathrm{l})$ in the blood of rats $(M+t m ; p=0.05 ; n=$ 6)

\begin{tabular}{|c|c|c|}
\hline Group & Results & Effects, $\%$ \\
\hline Intact & $\begin{array}{c}8.1233 \\
(7.5347 \div 8.7120) \\
\end{array}$ & - \\
\hline Control & $\begin{array}{c}18.4750 \\
(17.1510 \div 19.7990)\end{array}$ & - \\
\hline Alcoholic extract (at a dose of $110.5 \mathrm{mg} / \mathrm{kg}$ ) & $\begin{array}{c}12.9900 \\
(11.3146 \div 14.6654)\end{array}$ & $29.7 \%$ \\
\hline Alcoholic extract (at a dose of $221 \mathrm{mg} / \mathrm{kg}$ ) & $\begin{array}{c}10.2583 \\
(8.4301 \div 12.0866) \\
\end{array}$ & $44.5 \%$ \\
\hline Alcoholic extract (at a dose of $442 \mathrm{mg} / \mathrm{kg}$ ) & $\begin{array}{c}12.0817 \\
(10.7164 \div 13.4470) \\
\end{array}$ & $34.6 \%$ \\
\hline Alcoholic extract (at a dose of $663 \mathrm{mg} / \mathrm{kg}$ ) & $\begin{array}{c}12.4683 \\
(9.7329 \div 15.2038) \\
\end{array}$ & $32.5 \%$ \\
\hline Alcoholic extract (at a dose of $1105 \mathrm{mg} / \mathrm{kg}$ ) & $\begin{array}{c}14.8783 \\
(13.8824 \div 15.8743)\end{array}$ & $19.5 \%$ \\
\hline $\begin{array}{c}\text { "Glouqueir" Capsules, Shrey Nutraceuticals \& } \\
\text { Herbals Pvt. Ltd.", India (at a dose of } 500 \mathrm{mg} / \mathrm{kg} \text { ) }\end{array}$ & $\begin{array}{c}13.1417 \\
(11.4020 \div 14.8813)\end{array}$ & $28.9 \%$ \\
\hline $\begin{array}{l}\text { "Glouqueir" Capsules, Shrey Nutraceuticals \& } \\
\text { Herbals Pvt. Ltd.", India (at a dose of } 1000 \mathrm{mg} / \mathrm{kg} \text { ) }\end{array}$ & $\begin{array}{c}11.6667 \\
(10.3428 \div 12.9906)\end{array}$ & $36.9 \%$ \\
\hline $\begin{array}{c}\text { "Glouqueir" Capsules, Shrey Nutraceuticals \& } \\
\text { Herbals Pvt. Ltd.", India (at a dose of } 1500 \mathrm{mg} / \mathrm{kg} \text { ) }\end{array}$ & $\begin{array}{c}13.2850 \\
(10.9474 \div 15.6226)\end{array}$ & $28.1 \%$ \\
\hline $\begin{array}{l}\text { "Diabeton MR" } 60 \mathrm{mg} \text { tablets with modified } \\
\text { release, "Les Laboratoires Servier", France } \\
\text { manufactured by: "Les Laboratoires Servier } \\
\text { Industrie", France (at a dose of } 60 \mathrm{mg} / \mathrm{kg} \text { ) }\end{array}$ & $\begin{array}{c}12.2250 \\
(10.7214 \div 13.7286)\end{array}$ & $33.8 \%$ \\
\hline $\begin{array}{l}\text { "Diabeton MR" } 60 \mathrm{mg} \text { tablets with modified } \\
\text { release, "Les Laboratoires Servier", France } \\
\text { manufactured by: "Les Laboratoires Servier } \\
\text { Industrie", France (at a dose of } 120 \mathrm{mg} / \mathrm{kg} \text { ) }\end{array}$ & $\begin{array}{c}6.0417 \\
(4.3611 \div 7.7222)\end{array}$ & $67.3 \%$ \\
\hline $\begin{array}{l}\text { "Diabeton MR" } 60 \mathrm{mg} \text { tablets with modified } \\
\text { release, "Les Laboratoires Servier", France } \\
\text { manufactured by: "Les Laboratoires Servier } \\
\text { Industrie", France (at a dose of } 180 \mathrm{mg} / \mathrm{kg} \text { ) }\end{array}$ & $\begin{array}{c}13.1650 \\
(11.3164 \div 15.0136)\end{array}$ & $28.7 \%$ \\
\hline
\end{tabular}

The data obtained indicate that the tested alcoholic extract possesses significant hypoglycemic activity comparable to that of the capsule preparation "Glouqueir", "Shrey Nutraceuticals \& Herbals Pvt. Ltd.", India.

In the case of comparing the hypoglycemic activity of the tested alcoholic extract with the synthetic preparation "Diabeton MR" $60 \mathrm{mg}$ tablets with modified release, "Les Laboratoires Servier", France, it can be said that the lower hypoglycemic activity of the tested alcoholic extract can be explained by the fact that the herbal medicinal products at least and have less pharmacological action in contrast to synthetic agents, yet they have greater harmlessness, which makes them relevant in the treatment of internal diseases.

Based on the results obtained, a therapeutic dose range for the tested alcoholic extract was established, and a dose of $221 \mathrm{mg} / \mathrm{kg}$ can be recommended as the most effective dose.

The data obtained for the effective doses $\mathrm{ED}_{30}=90 \mathrm{mg} / \mathrm{kg}, \mathrm{ED}_{50}=100 \mathrm{mg} / \mathrm{kg}$ and $\mathrm{ED}_{100}=221 \mathrm{mg} / \mathrm{kg}$ can serve as a basis for calculating the starting and subsequent doses for clinical trials. 


\section{Conclusions}

The hypoglycemic activity of the preparation of the alcoholic extract of the preparation was studied in comparison with the reference preparations, according to the results of which it was established that the tested alcoholic extract contained reliable hypoglycemic activity comparable to the reference preparation "Gluqueir" capsule, "Shrey Nutraceuticals \& Herbals Pvt. Ltd.", India, but inferior to the synthetic preparation "Diabeton MR" $60 \mathrm{mg}$ tablets with modified release, "Les Laboratoires Servier", France, produced by: "Les Laboratoires Servier Industrie", France. The range of effective doses was also established and the most effective dose of the alcoholic extract was determined and the $\mathrm{ED}_{30}, \mathrm{ED}_{50}$ and $\mathrm{ED}_{100}$ were determined.

Preclinical studies of the alcoholic extract were carried out in comparison with the reference preparations "Gluqueir" capsules, "Shrey Nutraceuticals \& Herbals Pvt. Ltd.", India, and "Diabeton MR 60" mg modified release tablets, "Les Laboratoires Servier" France, in terms of hypoglycemic activity. As a result, it was found that an alcoholic extract with significant hypoglycemic activity comparable to the reference preparation "Glouqueir" capsules, "Shrey Nutraceuticals \& Herbals Pvt. Ltd.", India, but inferior to the synthetic preparation "Diabeton MR" $60 \mathrm{mg}$ tablets with modified release, "Les Laboratoires Servier", France, produced by: "Les Laboratoires Servier Industrie", France. The range of effective doses $\left(\mathrm{ED}_{30}, \mathrm{ED}_{50}\right.$ and $\left.\mathrm{ED}_{100}\right)$ was also established and the most effective dose was found.

\section{References}

1. N.Ch. Namozov, D.A. Kodirova, M.I. Usmonova, International journal of scientific \& technology research, 9(03), 5491-5493 (2020)

2. M. Urmanova, A. Kuziev, D. Burkhanova, D. Kadirova, N. Namozov, N. Shadieva, E3S Web of Conferences, 244, 02036 (2021)

3. S. Islamov, N. Namozov, M. Saidova, D. Kodirova, E3S Web of Conferences, 244, 03028 (2021)

4. A.K. Ganiev, A.K. Akhmedjanova, S.N. Umarov, O.R. Kakhkharov, B.B. Temirov, B.A. Nigmatullaev, S. Sunnatov, A Guide for Specialists in the Cultivation and Preparation of Medicinal and Spicy Plants, 192 (VS PRINT CENTER Press, Tashkent, 2020)

5. A. Mollica, G. Zengin, M. Locatelli, A. Stefanucci, A. Mocan, G. Macedonio, S. Carradori, O. Onaolapo, A. Onaolapo, J. Adegoke, M. Olaniyan, A. Aktumsek, E. Novellino, Journal of Functional Foods, 35, 32-42 (2017)

6. H. Vahida, H. Rakhshandehb, A. Ghorbani, Biomedicine \& Pharmacotherapy, 92, 293-302 (2017)

7. A. Kheirollah, M. Aberumand, Z. Ramezani, F. Amraee. J Nat Pharm Prod., 10(4), e24331 (2015)

8. R.A. Kulmatov, A.A. Kist, IND. LAB, 44(12), 1689-1692 (1978)

9. A. Carrera-Lanestosa, Y. Moguel-Ordóñez, M. Segura-Campos, J. Med. Food., 20(10), 933-943 (2017)

10. V.M. Emets, R.A. Kulmatov, Doklady Biological Sciences, 271(1-6), 370-372 (1983)

11. R.A. Kulmatov, V.S. Savenko, N. Dalonov, Geochemistry International, 29(5), 140148 (1992)

12. V.S. Savenko, R.A. Kulmatov, Geochemistry International, 35(11), 1028-1030 (1997) 